\title{
Studi Kualitatif Perilaku Keselamatan dan Kesehatan Kerja (K3) Petugas Instalasi Gizi Rumah Sakit pada Program Pencegahan Infeksi
}

\author{
Daru Lestantyo, ${ }^{1}$ Zahroh Shaluhiyah, $^{2}$ Siswi Jayanti ${ }^{1}$ \\ ${ }^{1}$ Departemen K3 Prodi S1 Kesehatan Masyarakat, Fakultas Kesehatan Masyarakat, \\ Universitas Diponegoro \\ ${ }^{2}$ Magister Promosi Kesehatan, Fakultas Kesehatan Masyarakat, Universitas Diponegoro
}

\begin{abstract}
Abstrak
Latar belakang: Infeksi yang terjadi saat seseorang menjalani perawatan medis saat ini menjadi perhatian banyak rumah sakit. Selain faktor resistensi kuman, perilaku petugas medis merupakan faktor risiko yang diduga menyebabkan kejadian tersebut. Perilaku yang dimaksud pada umumnya terkait dengan sanitasi dan higiene pribadi serta aspek keselamatan dan kesehatan kerja (K3). Penelitian ini bertujuan untuk menganalisis perilaku K3 staf instalasi gizi rumah sakit dalam menunjang program Pencegahan dan Pengendalian Infeksi $(P P I)$.

Metode: Penelitian dilakukan secara kualitatif dengan teknik observasi dan wawancara mendalam. Informan dipilih dengan teknik purposive dari populasi terjangkau. Informan utama sejumlah 6 orang dan informan triangulasi sejumlah 3 orang.

Hasil: Pengukuran suhu tempat kerja menunjukkan bahwa area produksi menunjukkan suhu tertinggi dibanding area pemorsian. Mayoritas informan memiliki pengetahuan dan sikap yang baik terhadap aspek K3 di tempat kerja. Hasil pengamatan menunjukkan bahwa praktik K3 petugas belum dilakukan sesuai standar. Penggunaan APD dan kepatuhan terhadap prosedur yang aman menjadi aspek yang paling banyak teramati.

Kesimpulan: Diharapkan institusi rumah sakit dapat melakukan brifing dan evaluasi terarah terhadap pelaksanaan safe food handling dan K3 untuk pencegahan infeksi.

Kata Kunci: Infeksi nosokomial, Instalasi Gizi rumah sakit, Lingkungan Kerja, Perilaku K3

\section{Qualitative Study of Safety and Health Behavior of Hospital Food Handler Towards Infection Prevention and Control Program}

\begin{abstract}
Background: Hospital associated infection was considered as the most common threat for hospitalized patient. Indonesia Ministry of Health's had officially issued the infection prevention program in 2017. Nowadays the implementation was considered to be evaluate facing the new global standard of hospital safety and facility management. This study aimed to analyze health and safety behavior amongs hospital kitchen staff in supporting the Infection Prevention and Control program (IPC).

Method: The research was conducted qualitatively by observation and in-depth interview method. Informants were selected using the purposive technique from targeted population. The main informants were 6 people of food handlers and the triangulation informants were 3 people from kitchen head and supervisors.

Result: Workplace indoor temperature of production area was $31^{\circ} \mathrm{C}$. This was relatively high compared to Indonesian Regulation. In-depth interview result indicate that majority of informants have good knowledge and attitude towards personal hygiene and sanitation. The observations showed that some participants did not comply safe operational procedure. The use of PPE and their compliance with safe procedures are the most important observed aspects.

Conclusion: It is expected that hospital institutions can conduct routine briefing and make deep evaluation of the safe food handling practice, safety procedure and infection prevention thoroughly.

Keywords: Food safety, hospital acquired infections, hospital kitchen, safety behavior
\end{abstract}

\footnotetext{
Alamat korespondensi:

Daru Lestantyo

Departemen K3 Prodi S1 Kesehatan Masyarakat

Fakultas Kesehatan Masyarakat, Universitas Diponegoro

Email: darulestantyo@live.undip.ac.id
} 


\section{PENDAHULUAN}

Infeksi yang didapat pasien saat melakukan pengobatan di rumah sakit merupakan tema yang banyak diangkat pada berbagai riset kesehatan maupun medis. Resistensi bakteri dan perilaku pasien maupun petugas medis merupakan faktor yang diperkirakan menjadi penyebabnya. Pengendalian infeksi nosokomial memerlukan tindakan dari berbagai aspek yaitu lingkungan kerja, perilaku kesehatan dan pemantauan kesehatan pekerja rumah sakit. Tantangan penanggulangan infeksi nosokomial khususnya yang disebabkan oleh $S$. aureus adalah meningkatnya pola resistensi bakteri terhadap antibiotik dalam dua dekade terakhir. ${ }^{1}$ Pola pajanan $S$. aureus terutama golongan Methycillin Resistant S. aureus (MRSA) saat ini mulai bergeser pada kelompok komunitas masyarakat diluar rumah sakit (community acquired MRSA-CA MRSA ). Berbagai studi menyimpulkan bahwa temuan MRSA di masyarakat bersumber pada individu yang tertular pada saat mengalami rawat inap. Studi pada sejumlah rumah sakit bahkan menghasilkan data lebih dari $40 \%$ temuan infeksi MRSA telah didapatkan sebelum pasien mendaftar sebagai pasien. ${ }^{2}$ Penelitian di Etiopia dengan responden masyarakat menunjukkan bahwa 20,5 \% responden merupakan karier $S$. aureus dan 9,8\%-nya merupakan MRSA ${ }^{3}$

Dalam kaitan dengan $H A I$, instalasi gizi rumah sakit juga memiliki potensi sebagai sumber infeksi nosokomial terhadap pasien maupun staf. Secara global, infeksi saluran cerna maupun keracunan makanan tidak dapat lagi dianggap memiliki prevalensi rendah. Kasus gastroenteritis yang disebabkan oleh infeksi mikroorganisme patogen di Amerika Serikat tahun 2012 tercatat 19.531 kasus dan 4563 diantaranya harus dilakukan tindakan spesialistik ke RS. Bakteri utama penyebab infeksi adalah Campylobacter dan E.coli. ${ }^{4}$ Sejumlah studi berhasil mendata jenis-jenis kuman yang sering menjadi pencemar dalam makanan yaitu Escherichia coli, Stafilokokus fekalis dan Clostridium perfringens. ${ }^{5}$ Data yang sedikit berbeda didapat pada Ditjen PPM dan PL Kemenkes RI tahun 1995 - 2000 yang mencatat bahwa penyebab tersering keracunan makanan di Indonesia adalah V. Cholera, S. aureus, jamur dan E.coli-Pseudomonas. ${ }^{6}$
Pada penelitian lain didapatkan data gastroenteritis yang disebabkan bakteri di Taiwan berhubungan dengan temuan Salmonella Spp dan S. Aureus sebagai penyebab terbanyak. ${ }^{7}$ Beberapa kasus mengindikasikan adanya kontaminasi yang berasal dari penjamah makanan. Penelitian ini bertujuan untuk menganalisis perilaku K3 staf instalasi gizi rumah sakit dalam menunjang program Pencegahan dan Pengendalian Infeksi (PPI).

\section{METODE}

Penelitian bersifat kualitatif dengan metode observasi dan indepth interview. Populasi target adalah petugas instalasi gizi rumah sakit yang bekerja sebagai food handler. Informan dipilih dengan teknik purposive dari populasi terjangkau. Informan utama sejumlah 6 orang food handler, sedangkan informan triangulasi sejumlah tiga orang adalah kepala instalasi gizi dan dua orang penyelia shift. Kriteria informan utama yaitu masa kerja telah lebih dari 12 bulan, pendidikan formal minimal SMK dan usia lebih dari 20 tahun. Informed consent dilakukan sebelum wawancara dan observasi. Ethical clearance diperoleh dari Fakultas Kesehatan Masyarakat Undip dengan nomor surat no 50/EC/FKM/2017.

Observasi dilakukan terhadap sarana prasarana dapur dan praktik $\mathrm{K} 3$ informan utama. Instrumen observasi adalah ceklis. Wawancara mendalam dilakukan terhadap informan utama dan triangulasi. Aspek yang ditanyakan dalam pedoman wawancara adalah pengetahuan, sikap dan praktik K3 informan.

\section{HASIL \\ Lingkungan kerja}

Pengambilan data lingkungan dilakukan terhadap aspek pencahayaan dan suhu tempat kerja. Dapur atau instalasi gizi di rumah sakit merupakan lingkungan kerja dengan berbagai potensi bahaya. Pencahayaan dan suhu adalah salah satu hazard yang memiliki risiko tinggi terjadinya kecelakaan atau penyakit akibat kerja. Hasil penelitian menunjukkan bahwa suhu ruang produksi di atas Nilai Ambang Batas (NAB) yang diizinkan yaitu $32,8^{\circ} \mathrm{C}$. Kondisi ini dapat memicu terjadinya penyakit atau kecelakaan kerja akibat pajanan panas. 
Tabel 1. Hasil Pengukuran Suhu Lingkungan Kerja (ISBB ${ }^{0} \mathrm{C}$ )

\begin{tabular}{lcccc}
\hline Lokasi & Pagi & Siang & Malam & Rerata \\
\hline Pengolahan 1 & 28 & 31 & 26 & 28,33 \\
Pengolahan 2 & 28 & 31 & 26 & 28,33 \\
Pemorsian & 24 & 30 & 24 & 26 \\
Gudang & 20 & 20 & 20 & 20
\end{tabular}

Pajanan panas di ruang kerja akan menyebabkan dehidrasi dan dalam jangka waktu lama dapat berakibat kegagalan fungsi ginjal. Berbagai studi menunjukkan bahwa dampak gangguan kerja ginjal dapat muncul pada pekerja dengan masa kerja di atas 5 tahun. Gangguan kerja ginjal yang kronis ini pada akhirnya dapat berdampak pada gagal ginjal. Kondisi lingkungan dengan suhu tinggi dan ekstrim akan semakin memperberat kerja sistem ekskresi oleh karena terjadinya evaporasi untuk menyeimbangkan temperatur tubuh (sistem homeostasis). Lingkungan kerja dan kebiasaan responden dalam konsumsi cairan merupakan faktor yang berpengaruh besar pada gangguan fungsi ginjal.

Hasil pengukuran pada empat lokasi di dalam instalasi gizi menunjukkan bahwa ruang pemorsian memiliki risiko pajanan suhu yang paling tinggi. Angka tersebut masih belum melewati NAB Permenaker 5 tahun 2018, namun sudah memerlukan pengawasan pada kondisi kesehatan pekerja.

\section{Pengetahuan}

Hasil wawancara mendalam menunjukkan bahwa semua informan memiliki pengetahuan K3 yang baik. Aspek pengetahuan yang dinilai adalah higiene sanitasi individu, keselamatan proses dan kesehatan kerja.

- Setiap petugas yang kontak dengan makanan harus tahu tentang bahaya infeksi yang dapat menular di produk (makanan) bagi pasien. Kuman berbahaya dapat menempel pada telapak tangan atau baju apabila tidak melakukan prosedur cuci tangan dengan baik. Apabila kita sedang sakit flu harus menggunakan masker agar tidak menular." ( IU 3)

Sebagian besar pengetahuan informan didapat dari brifing yang dilakukan rumah sakit pada awal shift. Penyelia shift bertindak selaku peer educator untuk memberikan materi tentang pencegahn infeksi dan kesehatan kerja

"Setiap awal shift, para supervisor akan memimpin brifing dan memberikan materi singkat tentang pencegahan infeksi termasuk kesehatan kerja dan food hygiene. Tujuan pemberian materi tersebut adalah untuk mengingatkan staf agar selalu bertindak sesuai prosedur." ( IT2).

Layanan jasa seperti rumah sakit, pada umumnya akan menggunakan pelatihan sebagai upaya untuk meningkatkan pengetahuan dan ketrampilan staf. Penerapan pelatihan untuk mengubah pengetahuan responden memerlukan ketepatan dalam pemilihan materi dan metode pengajarannya.

\section{Sikap}

bahwa Hasil wawancara menunjukkan pelaksanaan K3 dan PPI sudah mendukung. Melakukan prosedur pekerjaan dengan benar sesuai pedoman akan berdampak pada menurunnya risiko penularan penyakit maupun infeksi nosokomial. Salah satu yang menjadi substansi wawancara adalah kepatuhan pada prosedur kerja.

"Saya dan teman - teman selalu berusaha untuk mengikuti prosedur kerja yang aman. Kalau tidak patuh kami akan diberi peringatan dan mungkin bisa diskors. Tapi ya gak apa-apa demi kebaikan bersama. Kalau ada pasien atau karyawan yang tekena infeksi saya juga merasa bersalah." (IU5).

Pengawasan dan supervisi selalu menjadi fokus para penyelia. Pengawasan disertai pemberian penghargaan bagi yang dianggap dapat menjadi panutan telah dilakukan secara rutin.- Kami selaku kepala instalasi berusaha memberikan pengertian tentang pentingnya bekerja sesuai prosedur keselamatan dan PPI. Sebisa mungkin tidak diberikan hukuman bagi yang melanggar namun justru akan diberi pengarahan sekaligus dilatih agar terbiasa bekerja dengan benar." (IT1)

\section{Praktik K3 dan Pencegahan Infeksi}

Observasi yang dilakukan terhadap informan menunjukkan bahwa masih ditemukan pekerjaan yang dilakukan tidak sesuai prosedur. Temuan lainnya adalah penggunaan APD yang 
tidak sesuai dan tidak lengkap. Analisis terhadap jawaban informan saat wawancara menunjukkan bahwa rekan kerja memiliki pengaruh terhadap perilaku ini.

"Sebetulnya saya tahu kalau saat bekerja harus sesuai aturan dan pakai APD. Tapi ya sering lihat teman ngga pakai jadi ikutan juga. Padahal kalau ketahuan ya dimarahi. Rasanya panas kalau pakai apron dan maskernya itu buat sesak nafas. "( IU5)

\section{PEMBAHASAN}

\section{Lingkungan kerja}

Dehidrasi yang terjadi secara fisiologis akan berpengaruh pada aliran darah otak dan menyebabkan penurunan kewaspadaan. ${ }^{8}$ Studi pada petani di negara Thailand menunjukkan adanya hubungan suhu lingkungan dan angka kecelakaan kerja. ${ }^{9}$ Risiko pajanan panas terhadap kecelakaan kerja secara umum akan lebih tinggi pada pria dibanding wanita, namun pada pekerja dapur dapat menunjukkan sebaliknya karena mayoritas penjamah makanan adalah perempuan. ${ }^{10}$

Suhu tinggi di dalam ruang dapur juga berpengaruh pada kualitas makanan. Pertumbuhan kuman patogen pada makanan meningkatkan risiko keracunan dan infeksi saluran cerna. Proses produksi makanan memerlukan suhu lingkungan yang ideal agar tidak terjadi pertumbuhan kuman patogen pada makanan. Fasilitas dapur yang kurang mendukung dapat meningkatkan risiko kontaminasi makanan. ${ }^{5}$ Temperatur ruangan menjadi salah satu critical control pada penerapan food safety. Bahan makanan yang berbentuk daging hewan atau olahannya sangat sensitif terhadap perubahan suhu. ${ }^{11}$

\section{Pengetahuan}

Berdasarkan data sejumlah penelitian, pelatihan (training) ataupun model intervensi perilaku lainnya berdampak pada perubahan nilai pengetahuan responden. Pada umumnya pengetahuan responden yang baik akan mendorong terbentuknya sikap dan praktik yang baik. ${ }^{12}$ Penelitian yang dilakukan oleh Da Cunhae dkk di Brasil menunjukkan bahwa pelatihan yang hanya berbasis teori tidak menjamin perubahan sikap dan praktik responden. Pelatihan yang bertujuan pada pemenuhan aspek legislasi (sertifikat kompetensi, izin usaha, dll) secara empiris dianggap kurang dapat meningkatkan kompetensi peserta. Banyak pelatihan yang hanya dilakukan karena tuntutan perizinan atau sekedar bukti telah mengikuti kegiatan. ${ }^{13}$ Bentuk training yang tepat menurut beberapa studi adalah pelatihan yang sesuai dengan kebutuhan, kontinu dengan evaluasi yang tepat. ${ }^{14}$

Pengetahuan sebagai salah satu tolok ukur perilaku responden tidak hanya dipengaruhi dari aspek pendidikan formal atau pelatihan, namun juga berkaitan dengan masa kerja, usia dan budaya kerja. ${ }^{15}$ Pada penelitian ini, ditemukan bahwa pada kelompok kontrol juga terjadi kenaikan skor pengetahuan meskipun tidak dilakukan intervensi pelatihan. Hal ini dimungkinkan karena rentang usia yang relatif lebih muda maupun tingkat pendidikan pada kelompok kontrol sehingga masih memiliki motivasi belajar tinggi. ${ }^{16}$

\section{Sikap}

Penelitian yang dilakukan di Turki menunjukkan bahwa perubahan sikap responden akan terjadi apabila manajemen secara rutin memberikan penyuluhan dan supervise perilaku yang aman. ${ }^{17}$ Pengetahuan yang telah diberikan melalui penyuluhan sebaiknya juga ditingkatkan melalui pelatihan yang bertujuan meningkatkan ketrampilan karyawan. Keberhasilan pencegahan infeksi pada produk makanan rumah sakit sangat tergantung pada berbagai pihak yang terlibat sejak produksi hingga pengiriman ke pasien. Kualitas makanan harus tetap sama sejak keluar dari instalasi gizi hingga diterima pasien. Beberapa jenis mikroorganisma pathogen yang berisiko menimgkatkan keracunan antara lain $B$ cereus, $E$ coli, $S$ aureus , C perfringens dan Salmonella Spp. ${ }^{18}$

$S$. aureus merupakan bakteri patogen yang sering ditemukan pada permukaan tangan,dan lubang hidung. Selain itu area kulit yang mengalami luka juga menjadi tempat berkembang biak bakteri ini. Risiko keracunan terutama didapatkan dari enterotoksin yang diproduksi. ${ }^{19}$ Resistensi bakteri ini terhadap antibiotik perlu diwaspadai terutama pada golongan MRSA (Methycillin Resistant S.aureus). Studi yang dilakukan di Kuwait menunjukkan tingginya prevalensi MRSA pada food handler rumah makan yaitu sebesar $82 \%$ ( resisten terhadap Penicillin G). ${ }^{20}$ Studi-studi lanjut terhadap $\mathrm{S}$ aureus bahkan menyimpulkan bahwa bakteri ini menjadi penyebab kasus HAIs ( Hospital Acquired Infections) atau dulu dikenal dengan infeksi nosokomial. 


\section{Praktik K3 dan Pencegahan Infeksi}

Perilaku dan kepatuhan terhadap prosedur dan APD tidak mudah untuk dijadikan kebiasaan. Rendahnya pengetahuan diperkirakan menjadi penyebab masalah. ${ }^{21}$ Pelatihan dan pemberian penyuluhan merupakan kegiatan yang terbukti efektif untuk meningkatkan kesadaran perilaku sehat bagi food handler. ${ }^{22}$

-Masih banyak tenaga pejamah makanan yang memiliki pendidikan rendah. Kami selaku supervisor berusaha terus mengingatkan mereka agar bekerja sesuai prosedur dan memperhatikan prinsip pencegahan infeksi.Secara bertahap mereka dikirim mengikuti pelatihan pada unit pendidikan dan latihan (diklat) rumah sakit agar semakin baik kualitas pekerjaannya. Sayangnya materi pelatihan terkait safe food handling masih belum pas karena dikerjakan secara terpusat dan saat pembuatannya keterlibatan instalasi gizi sangat minim $\|$ (IT 2).

Saat ini telah banyak model pelatihan berbasis kompetensi yang dilakukan oleh organisasi. Salah satu syarat agar pelatihan tersebut dapat mengubah perilaku sasaran adalah kemampuan adaptif dari materi dan metode belajar pada pelatihan. ${ }^{23}$ Keberhasilan suatu pelatihan terhadap perbaikan perilaku ditentukan oleh banyak faktor. Beberapa studi menyebutkan faktor komitmen manajemen, tempat pelatihan yang representatif, jumlah peserta yang masih rasional serta kesempatan untuk praktik pada peserta merupakan syarat keberhasilan pelatihan. ${ }^{24}$ Hasil wawancara memberikan temuan bahwa RS belum secara rutin melakukan evaluasi terhadap kurikulum, metode dan kompetensi narasumber atau pelatih. Evaluasi peserta dalam bentuk pre maupun post test sudah dilakukan namun belum pernah dianalisis secara kuantitatif.

Kepatuhan dalam melakukan tahapan pekerjaan yang aman merupakan prasyarat keamanan pangan. Pennyediaan makanan di rumah sakit memiliki risiko yang berbeda dengan rumah makan biasa. Karakteristik pasien yang bervariasi terutama pada kondisi penyakit infeksi memrlukan persyaratan keamanan pangan yang ketat. Keracunan makanan dapat terjadi akibat kebiasaan pekerja yang kurang memperhatikan sanitasi individu. ${ }^{25}$ Kontak makanan dengan permukaan kulit tanpa sarung tangan atau sarung tangan yang tidak bersih merupakan contoh kasus yang sering ditemui pada dapur rumah sakit. Karakteristik pekerja merupakan salah satu hal yang dapat memperngaruhi kebiasaan sanitasi individu. Karakteristik terebut antara lain usia, tingkat pendidikan formal, masa kerja dan budaya setempat. ${ }^{26}$

\section{KESIMPULAN}

Penelitian ini menunjukkan bahwa banyak aspek yang berpengaruh terhadap perilaku pekerja. Komitmen manajemen RS dan dukungan terhadap pelaksanan program K3 merupakan modal dasar yang sangat penting. Lingkungan dapur RS memiliki banyak risiko salah satunya adalah faktor fisik. Pengukuran temperatur dalam ruang menunjukkan bahwa lokasi penelitian memiliki risiko yang berasal dari suhu tempat kerja. Suhu yang tinggi dapat menurunkan konsentrasi akibat dehidrasi dan menyebabkan kecelakaan kerja.

Perilaku K3 responden pada umumnya baik, namun masih ditemukan beberapa ketidaksesuaian antara pengetahuan dan sikap informan dengan praktik food handling. Pekerja masih memerlukan banyak pendampingan dan supervisi agar selalu bekerja sesuai prosedur. Pengaruh teman kerja masih cukup kuat dalam membentuk praktik responden. Sikap positif informan telah terbentuk dengan baik namun masih kurang kuat dalam implementasi dan parktik kerjanya. Materi dan metode pelatihan belum dibuat secara mandiri oleh pihak instalasi gizi melainkan dikerjakan oleh instalasi diklat RS.

Institusi rumah sakit sebaiknya melakukan safety briefing rutin yang berkaitan dengan K3 dan pencegahan infeksi. Inspeksi lingkungan kerja wajib dilakukan rutin untuk mengidentifikasi potensi bahaya dan risiko $\mathrm{K} 3$. Food handler secara rutin perlu diinspeksi kelengkapan APD maupun pengetahuan prosedur kerja yang aman. Staf gizi rumah sakit perlu diberikan pelatihan tentang pencegahan risiko infeksi maupun kecelakaan kerja.

\section{UCAPAN TERIMA KASIH}

Sejawat dosen di bagian K3 Prodi S1 Kesmas FKM Universitas Diponegoro dan mahasiswa peminatan K3 Prodi S1 Kesmas FKM Universitas Diponegoro

\section{DAFTAR PUSTAKA}

1. Pinchuk I V, Beswick EJ, Reyes VE. Staphylococcal enterotoxins. Toxins (Basel). 2010 Aug;2(8):2177-97.

2. Chambers HF. The changing epidemiology of Staphylococcus aureus? Emerg Infect Dis. 2001;7(2):178-82.

3. Dagnew M, Tiruneh M, Moges F, Tekeste Z. Survey of nasal carriage of Staphylococcus aureus and intestinal parasites among food handlers 
working at Gondar University, Northwest Ethiopia. BMC Public Health. 2012 Jan;12(1):837.

4. CDC. Morbidity and Mortality Weekly Report ( MMWR ) Incidence and Trends of Infection with Pathogens Transmitted Commonly Through Food - Foodborne Diseases Active Surveillance Network, 10 U. S . 2013.

5. Lund BM, O`Brien SJ. Microbiological safety of food in hospitals and other healthcare settings. J Hosp Infect. 2009 Oct;73(2):109-20.

6. Supraptini, Seregeg IG BS. Kejadian Keracunan Makanan dan Penyebabnya di Indonesia 1995-2000. J Ekol Kesehat. 2002;1(3):127-35.

7. T. H Chen JMC. Bacterial Foodborne Outbreaks In Central Taiwan 1991-2000. J Food Drug Anal. 2003;11(1):53-9.

8. Elizabeth P. NORMS AND STANDARDS FOR ENVIRONMENTAL HEALTH AND OCCUPATIONAL HYGIENE AT DISTRICT HOSPITALS. Durban, South Africa; 2001.

9. Tawatsupa B, Yiengprugsawan V, Kjellstrom T, Berecki-gisolf J, Seubsman $\mathrm{S}$, Sleigh A. Association between heat stress and occupational injury among Thai workers: Findings of the Thai cohort study. Ind Health. 2013;51:34-46.

10. Neilsen D, Austin J. Behavior-Based Safety: Improvement Opportunities in Hospital Safety. Prof Saf. 2005;(February):33-7.

11. Yousif EI, Ashoush IS, Donia a. a., Hala Goma $\mathrm{K}$ a. Critical control points for preparing chicken meals in a hospital kitchen. Ann Agric Sci. 2013 Dec;58(2):203-11.

12. Md Mizanur Rahman, Mohd.Taha Arif, Kamaludin bakar ZBT. Food safety Knowledge, Attitude And Hygiene Practices Among The Street Vendors in Northern Kuching City, Sarawak. Borneo Sci. 2012;(September):107-16.

13. Akonor PT, Akonor MA. Food Safety Knowledge: The Case of Domestic Food Handlers in Accra. Eur J Nutr Food Saf. 2013;3(3):99-111.

14. DA CUNHA DT, STEDEFELDT E, DE ROSSO VV. Perceived Risk of Foodborne Disease By School Food Handlers and Principals: the Influence of Frequent Training. J Food Saf.
2012;32(2):219-25.

15. Abdul-Mutalib N-A, Abdul-Rashid M-F, Mustafa S, Amin-Nordin S, Hamat RA, Osman M. Knowledge, attitude and practices regarding food hygiene and sanitation of food handlers in Kuala Pilah, Malaysia. Food Control. 2012 Oct;27(2):289-93.

16. da Cunha DT, Stedefeldt E, de Rosso VV. The role of theoretical food safety training on Brazilian food handlers' knowledge, attitude and practice. Food Control. 2014 Sep;43:167-74.

17. Baş M, Şafak Ersun A, Kivanç G. The evaluation of food hygiene knowledge, attitudes, and practices of food handlers' in food businesses in Turkey. Food Control. 2006;17(4):317-22.

18. Ayçıçek H, Sarimehmetoğlu B, Çakiroğlu S. Assessment of the microbiological quality of meals sampled at the meal serving units of a military hospital in Ankara, Turkey. Food Control. 2004 Jul;15(5):379-84.

19. Argudín MÁ, Mendoza MC, Rodicio MR. Food poisoning and Staphylococcus aureus enterotoxins. Toxins (Basel). 2010 Jul;2(7):1751-73.

20. Udo EE, Al-Mufti S, Albert MJ. The prevalence of antimicrobial resistance and carriage of virulence genes in Staphylococcus aureus isolated from food handlers in Kuwait City restaurants. BMC Res Notes. 2009 Jan;2:108.

21. Abdelhafez AM. Knowledge, Attitudes and Practices Of Food Service Staff About Food Hygiene In Makkah Area Saudi Arabia. Life Sci J. 2013;10.

22. Karen Glanz, Barbara K Rimer KV. HEALTH BEHAVIOR AND HEALTH EDUCATION. San Fransisco: JosseyBass; 2008.

23. Seaman P. Food hygiene training: Introducing the Food Hygiene Training Model. Food Control. 2010 Apr;21(4):381-7.

24. Vo TH, Le NH, Le ATN, Tran Minh NN, Nuorti JP. Knowledge, attitudes, practices and training needs of food-handlers in large canteens in Southern Vietnam. Food Control. 2015;57:190-4. 
25. Lawan U, Iliyasu Z, Abubakar S, Mudey AB. Health Status and Personal Hygiene among Food Handlers Working at Food Establishment around a Rural Teaching Hospital in Wardha District of Maharashtra , India. Glob Journals Heal Sci. 2010;2(2):198-206.
26. Gajida A, Abdussalam A. Personal and food hygiene practices of subsistence food vendors operating in Kano metropolis, northwestern Nigeria. Int J Med Sci Public Heal. 2014;4(2):1. 